\title{
釜石鉱山地下空間の音響実験と照明の試み
}

\author{
神谷 宏*・牧野 清*・石山宏二*

\section{The Test of Sound and Light for Utilization of Underground Rocky Cave (Kamaishi Mine Mable Hall)}

\author{
Hiroshi KAMIYA*, Kiyoshi MAKINO* and Koji ISHIYAMA*
}

\section{1. まえがき}

鍾乳洞や廃坑など岩盤がむき出しのままの状態にある 空洞に入ると, 天井から落ちる水滴の音や話し声は共鳴 することもなく，とても澄んだ音や声として聞きとれ る。これは岩石の種類にもよるが, 岩石そのものにも吸 音する物性があるためである。をた，空洞内は気温や湿 度などがほぼ一定の状態に保たれている。このような環 境は, 空間に抢ける音の伝わり方や拡散状況などについ て実験するには格好の場所でもある。

著者たちは，平成 4 年に釜石鉱山内に残されている 白色石灰岩の地下空間の有効利用を検討する機会を得た。

現在, 釜石鉱山では採掘跡の有効利用の研究開発とし て，白色石灰岩層以外の場所において，それぞれ目的に 応じた実験を行い続けてきている。

検討の条件としては，(1)従来鉱山内で実施してきてい る諸実験とは異質な，(2)金石という地名が生かせる地域 の活性化につながり，(3)地域の人々に楽しんでもらえる ような，(4)白色石灰岩を強調し，そして(5)釜石鉱山の地 下にはこんな大空間があるんだと訪れる人たちにいつま でも印象づけるようなこと，などを骨子とした。

検討の結果，白色石灰岩空洞内の，残響時間などの音 響特性が音楽ホールにも適することを主体に，緑・水 ・人工照明を使ってバランスよく構成し，コンサート ステージ・ギャラリー・憩いの広場などの施設を配置 し，地上の生活と変わりのない，人々が集まり，休皕

* 西松建設(㑣技術研究所 Technical Research \& Developement institute, Nishimatsu Construction Co., Ltd.
し，語り合うことのできる情景の演出の可能性を探求し た。

本報では,この実験の概要と結果について報告する。

2. マーブルホールとは

イベント実験を行ったマーブルホールは，地下 900 $\mathrm{m}$ にある白色石灰岩層をくり抜いた高さ $4 \mathrm{~m}$, 幅 $60 \mathrm{~m}$, 奥行き $80 \mathrm{~m}$, 全容積 $12,000 \mathrm{~m}^{3}$ の空間で, 全面純度 $90 \%$ 以上を有する白色石灰石で囲まれ, 年中気温 $12^{\circ} \mathrm{C}$, 湿度 $90 \%$ の肌寒さを感ずる大空洞である。空洞には, 石灰岩の採掘時に空洞の安定上必要な巨大な柱（5 $\mathrm{m} \times 5 \mathrm{~m})$ が 18 本残されている。そのため, 空洞内は格 子状の通路に分割された状態となっており, 光を当てる ことで明暗がはっきりと映し出され，さらに，巨大な柱 の陰にうすい光が見える幻想的な白要の世界に誘われた ような雾囲気である。

\section{3. イベント実験}

音響・照明の基礎実験を踏をえ,このマーブルホール をひとつのイベントスペースとして計画し，その可能性 を探る。基本的な構想としては, 真白な石と林立する巨 柱，そして暗闇という特異な空間に「光・音・水」を持 ち込反，オアシス的なものと末来的・宇宙的空間という もの, さらに芸術的なものとしてどう表現するかにあっ た。この基本構想をもとに作り出したシーンの情景につ いて説明する。(図一1)

\section{1 アプローチ（写真 -1 )}

地下 $900 \mathrm{~m}$ にあるマーブルホールへは, 水平坑, 斜 坑, そしてまた水平坑へと約 $4 \mathrm{~km}$ 程の坑道をトロッコ 
- 白色石灰岩の地下岩盤空洞 大深度地下一地表下 $900 \mathrm{~m}$ 奥行 $\fallingdotseq 80 \mathrm{~m}$ 幅 $\fallingdotseq 60 \mathrm{~m}$ 高さ $\fallingdotseq 4 \mathrm{~m}$ 全容積 $12,000 \mathrm{~m}^{3}$

・ ニューフロンティア空間 としての地下空洞

- 色と光と影と音の 有機的な調和を求める 閤·静 $\rightarrow$ 明·動

- シーン名称

1 河童の池

2 光の壁

$3 ・ 4$ 水の演出

5 光の列柱

6 ホログラム

7 休想コーナー

8 石のステージ

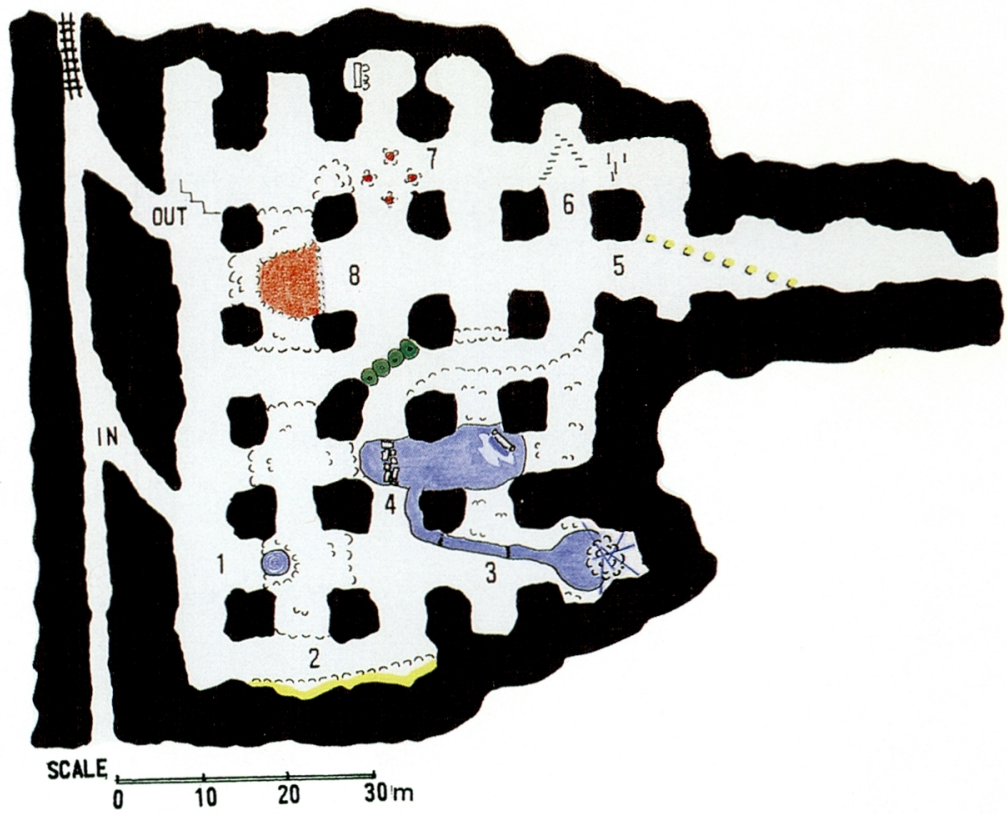

図 - 1 釜石鉱山マーブルホール・イベント実験プラン

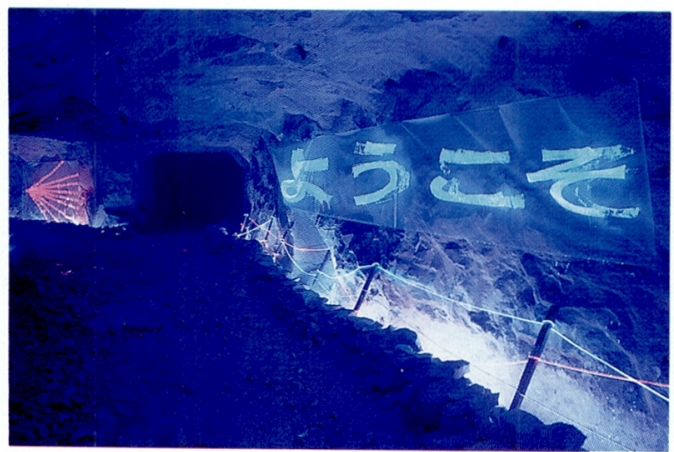

写真-1 アプローチ

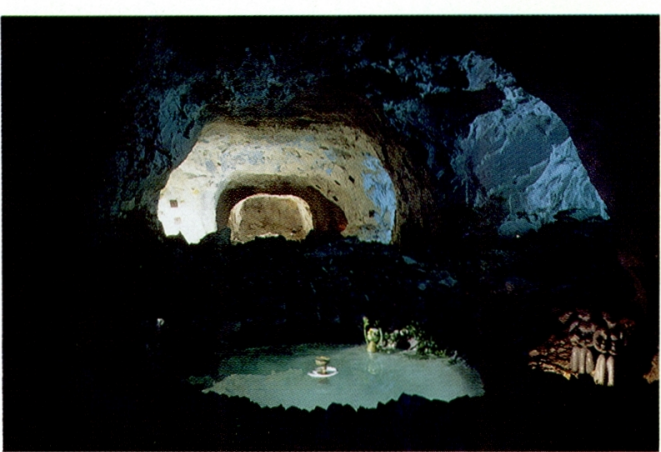

写真 -2 河童の池
を乗り継いで行く。所要時間は約 40 分程である。マー ブルホールに近づくと, 坑道は暗闇となり, さらに, ブ ラックライトと蛍光塗料によって怪しく光るトンネルに 導かれ，「上うこそ」の歓迎を受けながらホールへと歩 み進む。

\section{2 河童の池（写真 -2 )}

民話の古里として有名な遠野に因んで「河童の池」を 作った。直径 $3 \mathrm{~m}$, 深さ $1.5 \mathrm{~m}$ の穴をすり鉢状に掘り, そこへ坑道から湧き出る天然水（仙人秘水）を入れた。 石灰岩によって程よく白濁したその池にポンプを入れ泡 を出し，スポットライトを用意。あたりから“蛙の合唱”
“河童のささやき”などをイメージした音を聞かせ，池 の中からポコリと河童（漫画家, 牧野圭一氏創作）が浮 かび上がるという仕掛けで演出した。

\section{3 光の壁}

このシーンでは, 高さ $4 \mathrm{~m}$, 長さ $20 \mathrm{~m}$ の岩盤に光を あて, その大きさ, 白さ, 岩肌の粗さなど白色石灰岩の 持つ表情を壮大な音とともにアレンジしてみた。

\section{4 水の演出, 光の列柱 (写真 -3 )}

このシーンでは, 白色石灰岩の大空洞の中で「水」の 一生というものを，湧き出す誕生から蒸発し消滅するま でをまとめて演出した。緑，水の音そして虫の音の共演 


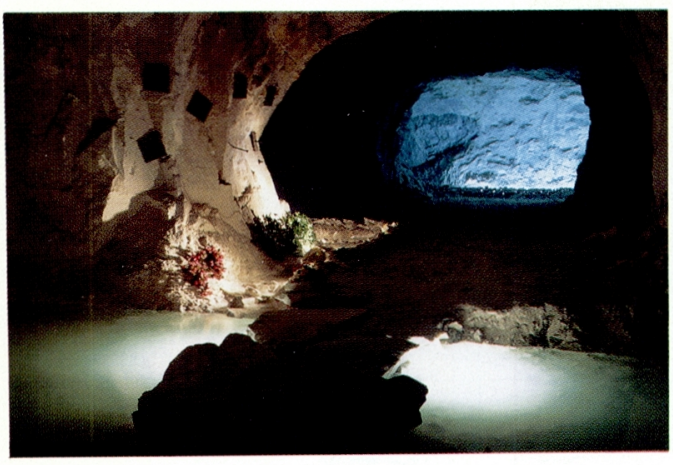

写真 -3 水の演出

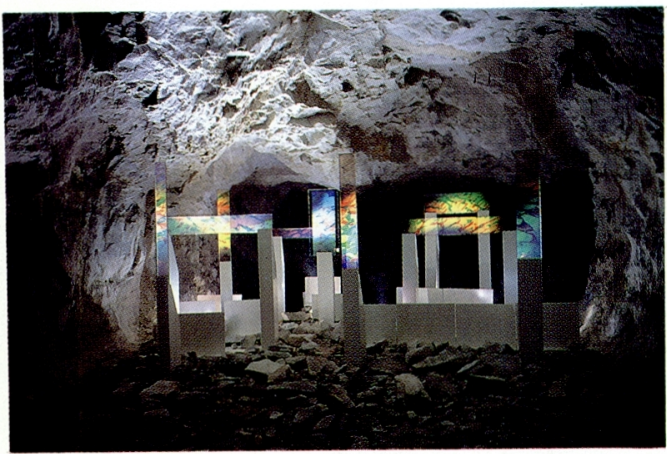

写真 -4 ホログラム 1

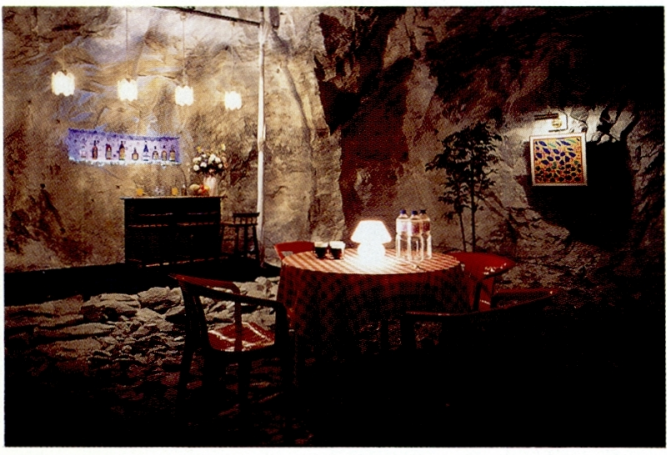

写真 -5 休愁コーナ

で，オアシス的な雾井気を創ってみた。

噴水はズリによって作られた小山から噴き出し, やが て集められて細流（せせらぎ）となる。細流の底には光 ファイバーを設置し, 赤・青・黄の微光の中で白い石と 相まって神秘的流れを作り出した。大きな池には，水中 ライトを入れ, 池自体を発光させることで静寂感を演出 した。

「光の列柱」のシーンでは, 奥行きのある空間を利用

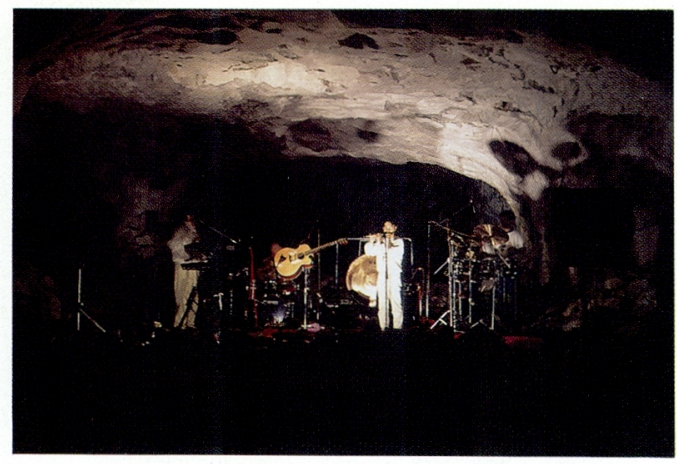

写真 - 6 大久保正人氏による邦楽の演奏

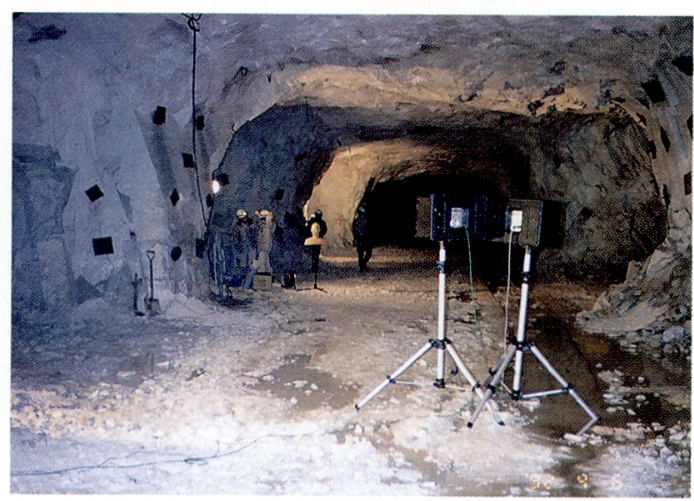

写真 -7 音響測定

して，光の柱を連続的に立ち上げた。ライトの脇には噴 霧を発生するノズルを設置し, 複数のスピーカによって 空間を飛び回る音とともに噴き上げた。噴霧の中で光柱 をきれいに投影させるために緑色のフィルターを使用し た。

\section{5 ホログラム (写真 -4$)$}

全面白色の岩壁に覆われたブースをギャラリーに見立 て, 石井勢津子氏の作品（ホログラフィーアート）を展 示した。ホログラムは, レーザー光線を使って透明なつ ィルムに彫刻し, ガラス板で表面加工した芸術作品であ る。光の反射・屈折を利用することで彫刻は立体的にさ まざまな「彩」が見られ，壁面や床にやわらかく映る透 明感のある幻想的な空間に誘われるようであった。

\section{6 休䄭コーナー (写真 -5 )}

ここでは人々が集う空間を想定。白に映える赤いテー ブルと椅子に白い小さなランプをのせ，見学者には天然 水（仙人秘水）の試飲サービス。むた, 壁面の一部をく り拔き，照明を組み込んだ光棚を作り，カウンターを持 ち込んでバーコーナーとした。所々に観葉植物を置き, 


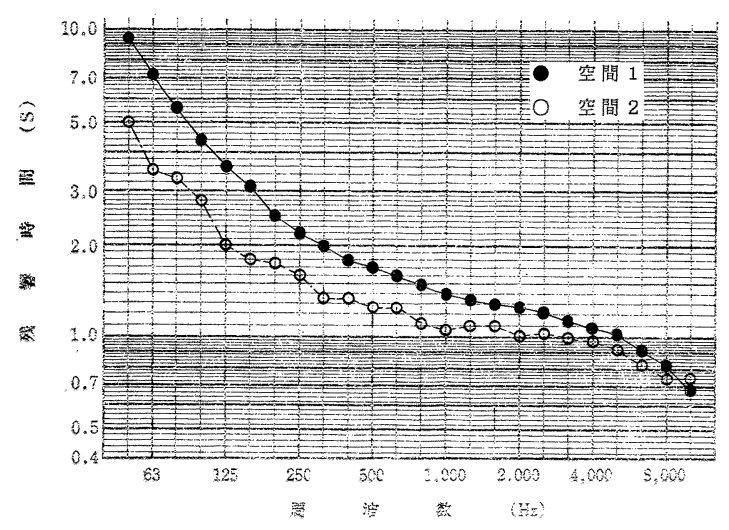

図-2 残響時間周波数特性

壁にはブラケット付の絵画を飾り，森をイメージにピア ノの音と鳥のさえずりが聞こえる BGM を流し，ゆった りとした雲囲気を作った。また，ビデオによる海中シー ン, プラネタリウムによる星座, 時計の投影など，白い 岩壁をスクリーンに見立てた実験も行った。

\section{7 石のステージ (写真-6)}

音楽ホールに見立てるために，大きな空間に石のステ 一ジを作った。 $7 \mathrm{~m} \times 5 \mathrm{~m}$ の赤いステージの周りはズり の小山で取り囲み, 四方に巨大な柱が立つ。照明は, 演 奏者用と天井や巨柱を色々に染める効果として使用し た。ステージでは, 今回のイベントで総合的な音楽づく りをしてくださった天山氏 (作曲家) による神秘的な幻 想音楽を聞いた。同時に, 音楽に合った光をステージ周 辺に投光し同調させた。そして最後のイベントとして， 地元のアマチュアバンドやプロの演奏家による生演奏を 試みた。

本実験で生演奏してくださった地元のプロ演奏家・大 久保正人氏は，その時の感想を「離れた所でむ近くに聞 こえ，音響学的にも面白い」と述べられていた。

\section{4. 基 礎 実 験}

\section{1 音響実験}

測定は，(1)残響時間，(2)音圧分布，(3)明瞭度試験 (RASTI)，(4)試聴およびダミーヘッド録音について， 空洞全体（空間 1）と空洞の一部分（空間 2) に分けて 行なった。

明瞭度試験は，B＆K 社 Type 3361によって RASTI 值を求めた。トランスミッタから外部スピーカに接続 し, 試験信号 $(500 \mathrm{~Hz})$ の音圧レベルを $80 \mathrm{~dB}$ に設定 した。

エコータイムパターンの音源には, 弾着（電圧をかけ

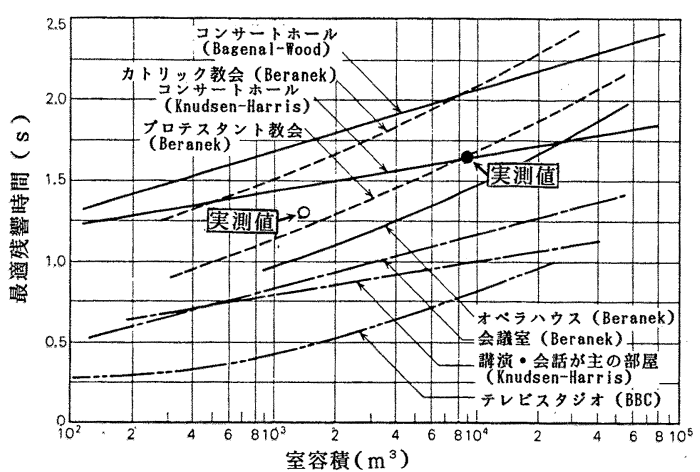

図 - $3500 \mathrm{~Hz}$ の最適残響時間と室容積 出典：建築設計資料集成

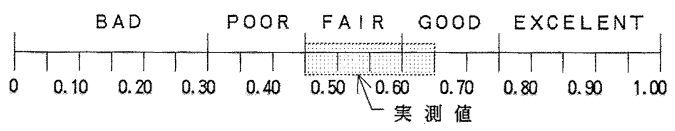

図-4 RASTI 值対主観明瞭度

て爆破させる爆竹）を用いた。 試聴，ダミーヘッド (高研社製) 録音では, 音源スピ 一カにBOSE802を用いてドライソースを再生, 試聴お よび録音した。

\section{2 測定結果}

(1) 残響実験

図-2 に空間 1 , 空間 2 の残響時間の平均値を示す。

空間 1 では，図-2の一点鎖線で示した範囲の 9 測定 点を平均したもので, $500 \mathrm{~Hz}$ の残響時間は1.7秒であ る。低音域に比べて中高音域では短めの值が得られた が，これは掘削時の粉塵が表面に付着していること，ズ リ（掘削層）が隅に集積されていることによる吸音力の 増加によるものと思われる。空間 2 では，1.3秒（500 $\mathrm{Hz}$ )であった。

ここで，容積毎の最適残響時間 $(500 \mathrm{~Hz})$ および既 存のホール・劇場の残響時間 $(500 \mathrm{~Hz})$ を比較したも のを図ー 3 に示す。これによれば，容積に対する500 $\mathrm{Hz}$ の残響時間は，コンサートホールにほぼ適している ことになる。

(2) 音圧分布

空間 1 は特殊な形状のため, 音源位置から見て右奥 は直接音がなく，ズリが集積されていることなどから大 きく減衰している。

(3) 明瞭度試験

RASTI の実測値と主観明瞭度の関係を図ー4 に示す。 この空洞においては, 直接音が届く場所では RASTI 值 が平均 0.6 程度で, 聴感上も比較的明瞭性が良かったが, 
柱の陰では $0.45,0.49 て ゙ ，$ 直接音成分が届かず左右から の反射音のみが到達するため, 聞き取りにくい状況だっ た。

(4) 試聴およびダミ一ヘッド録音

ドライソースを再生して試聴したところ，残響時間周 波数特性が示すように低音域の長さが気になるものの， 濁りのないクリアな音楽が聴けた。空間 1 では拡がり 感のある音場, 空間 2 ではパワー感のある音場といっ た空間の形状による違いが感じられ，どちらも音源から 20〜30 m ほど離れた位置が最も好ましく聴くことがで きた (写真 -7$)$ 。

\section{3 照明実験}

この実験では，白い岩壁に対して光の演出効果と視認 性を評価するために，岩盤に当てた時の光の見え方や拡 がり方を検討した。

その結果, 空間の形状や材質の特徴を引き出し, さま ざあな照明シーンを再現させたが，幻想的な世界の演出 をどれだけ表現できたか難しいものがあった。なた，印 象を深めるための方法として，視覚だけの表現では心理 的結果を引き出すのに満足できるものではなく，音響を 加味し聴覚にも訴える演出も効果的ではなかったかと思
われた。

\section{5.おわりに}

現在, 廃止鉱山で行われている跡地有効利用には, 大 学キャンパスゾーン・実験や研究施設・観光事業, 産業 廃棄物処分場・農業施設・オフロードコース, そして文 化財にと，それぞれの目的に応じた実例がある。この実 験は, マーブルホールという大自然そのものを生かし創 造したものであり, 鉱山のリフレッシュを違った視野か ら探求を試みた。

地下空洞そして白色石灰岩場という特殊な環境の中 で，「光・音・水」をどのようにアレンジし，幻想的な しかも神秘的な造形をいかに表現するか, 想像した各シ 一ンには反省点もあったが，全体的には満足のできる実 験ができた。

最後に，本実験の場を提供してくたさった日鉄鉱業 (侏)，実験に協力していただいた関係者に感謝の意を表し ます。

（1993年12月 20 日受付， 1994 年 2 月 9 日受理） 